Putri, T.K. - D. Veronika · A. Ismail · A. Karuniawan · Y. Maxiselly · A. W. Irwan $\cdot$ W. Sutari

\title{
Pemanfaatan jenis-jenis pisang (banana dan plantain) lokal Jawa Barat berbasis produk sale dan tepung
}

\section{Utilization kind of local West Java bananas (banana and plantain) based figs and flour product}

Diterima : 15 September 2015/Disetujui : 15 Oktober 2015 / Dipublikasikan : Oktober 2015

CDepartment of Crop Science, Padjadjaran University

\begin{abstract}
Banana is a horticultural commodity (fruit) that can be eaten immediately or processed. Banana is a fruit that is not durable, therefore efforts should be made to make it more durable and the sale is processed into flour. The purpose of this research was to analyze the use of several types of bananas for figs or flour. Organoleptic (test descriptions and hedonic test) Tests was conducted some banana fig and flour samples. The number of panelists that five people were taken randomly. The results are obtained the sale that made from banana Siem / Kepok in sample 2 has a sweet taste, a distinctive aroma, and texture that is preferred by the panelists of five people.
\end{abstract}

Keywords: Banana processing $\cdot$ Figs $\cdot$ Flour

Sari Pisang merupakan komoditas hortikultura (buah) yang dapat dimakan langsung atau diolah. Pisang merupakan buah yang tidak tahan lama, oleh karena itu perlu dilakukan upaya untuk menjadikannya lebih tahan lama adalah diolah menjadi sale dan tepung.Tujuan dari penelitian ini adalah untuk menganalisis pemanfaatan beberapa jenis pisang untuk sale atau tepung. Pengujian dilakukan secara organoleptik (uji deskripsi dan uji hedonik) beberapa sampel sale dan tepung pisang. Jumlah panelis yaitu lima orang yang diambil secara acak. Hasil yang diperoleh adalah sale yang terbuah dari pisang Siem/Kepok pada sampel 2 memiliki rasa manis, aroma khas, dan tekstur yang disukai oleh panelis yang berjumlah 5 orang.

Kata kunci : Olahan pisang · Sale $\cdot$ Tepung

\footnotetext{
Dikomunikasikan oleh Yudithia Maxiselly

Putri, T.K. 1. D. Veronika 1. A. Ismail 2. A. Karuniawan ${ }^{2}$. Y. Maxiselly 2. A. W. Irwan 2. W. Sutari ${ }^{2}$

1 Alumni Program Sarjana Agroteknologi Faperta Unpad

2 Dept. Budadaya Pertanian Fakultas Pertanian Unpad

Korespondensi: adeismail_unpad@yahoo.com
}

\section{Pendahuluan}

Pisang merupakan buah yang banyak dikonsumsi dalam bentuk segar. Permasalahan konsumsi pisang dalam bentuk segar adalah mudah rusak dan cepat mengalami perubahan mutu setelah panen, karena memiliki kandungan air tinggi dan aktifitas proses metabolismenya meningkat setelah dipanen (Demeriel dan Turban, 2003 dalam Histifarina dkk, 2012).

Tahun 2014 produksi pisang di Indonesia mencapai 7.008.407 ton (BPS, 2015). Produksi pisang di Indonesia yang cukup tinggi tidak sebanding dengan tingkat konsumsi masyarakat, sehingga mengakibatkan banyaknya pisang yang tidak dimanfaatkan karena daya simpan buah pisang yang relatif singkat. Solusi terbaik dari masalah ini adalah dengan membuat pisang menjadi produk olahan sale dan tepung. Pembuatan tepung dapat memperpanjang daya simpan pisang tanpa mengurangi nilai gizi. Solusi tersebut menjadi cara yang tepat untuk mengatasi tingginya produksi pisang dengan keterbatasan teknologi pasca panen yang ada. Syarat mutu sale pisang yang baik adalah kadar air maksimum $40 \%$, rasanya khas, baunya normal, tidak ada cemaran logam dan mikroba. Menurut (Prabawati dkk., 2008) pada dasarnya semua pisang dapat dibuat sale namun untuk jenis-jenis pisang tertentu kurang menghasilkan rasa yang enak. Berdasarkan hasil wawancara dengan pedagang dan pemilik home industri pada bulan Oktober 2015 masingmasing jenis sale terbuat dari berbagai jenis pisang. Pisang yang digunakan untuk membuat sale diantaranya adalah pisang ambon, pisang raja, pisang siem, dan pisang kapas. Menurut Prabawati dkk., (2008) pisang ambon, siem, dan 
raja merupakan jenis pisang yang memiliki rasa manis dan aroma yang kuat. Jenis pisang tersebut memiliki rasa manis yang kuat (Satuhu dan Supryadi, 2004). Pisang kapas menurut Heyne (1950) memiliki kandungan karbohidrat mencapai 29,74 \%, pisang ini memiliki rasa manis (Satuhu dkk., 1992). Pisang ambon dan pisang raja setelah dijemur menghasilkan rasa yang manis dengan warna kuning kecoklatan (IPB, 1982).

Semua jenis pisang pada umumnya dapat dijadikan tepung, namun jenis pisang yang digunakan mempengaruhi mutu tepung yang dihasilkan. Menurut Astawan (2005) dan Bappenas (2000) pisang buah (Musa paradisiaca) dapat digolongkan dalam 4 kelompok : (1) Musa pardisiaca var. sapientum (banana) yaitu pisang yang dapat langsung dimakan setelah matang atau pisang buah meja contoh : Pisang susu, hijau, mas, raja, ambon kuning, ambon, barangan, dll; (2) Musa Pardisiaca forma typiaca (plantain) yaitu pisang yang dapat dimakan setelah diolah terlebih dahulu, contoh : Pisang tanduk, uli, bangkahulu, kapas; (3) Pisang yang dapat dimakan setelah matang atau diolah dahulu, contoh: Pisang kepok dan raja serta; (4) Musa brachycarpa yaitu jenis pisang yang berbiji dapat dimakan sewaktu masih mentah, seperti pisang batu atau disebut juga pisang klutuk atau pisang biji. Masing-masing kelompok pisang tersebut mempunyai fungsi dan karakteristik berbeda.

Semua jenis pisang dapat dijadikan tepung baik dari jenis banana dan plantain. Jenis pisang yang lebih baik dijadikan tepung adalah dari jenis plantain. Pisang jenis plantain memiliki kadar pati yang lebih tinggi dan kadar gula yang lebih rendah dibandingkan jenis banana (Bender, 1999 dalam Palupi, 2012).

\section{Bahan dan Metode}

Beberapa sampel sale yang diperoleh di lapangan diuji dengan metode uji deskriptif dan uji hedonik. Uji deskriptif dilakukan untuk mengidentifikasi dan mengukur sifat-sifat sensori berdasarkan skala rasio sedangkan uji hedonik bertujuan untuk mengukur tingkat kesukaan konsumen terhadap suatu produk (Anonim, 2006). Jumlah panelis adalah lima orang. Parameter sale yang diuji pada uji deskriptif adalah rasa manis, rasa asam, pahit, tengik, dan aroma tengik.
Pisang yang digunakan untuk pembuatan tepung adalah pisang mentah yang sudah cukup matang. Pisang yang digunakan adalah pisang ambon kuning, pisang nangka, pisang muli, pisang raja sereh, pisang raja bulu, pisang siem, pisang kepok, pisang ambon lumut, pisang kapas, pisang ampyang, pisang susu, dan pisang tanduk. Pisang-pisang tersebut kemudian dikukus selama \pm 10 menit. Proses pengukusan tersebut adalah proses blansir. Blansir adalah proses perebusan bahan pangan dengan air panas atau uap panas. Blansir dapat mencegah pencoklatan dengan mekanisme menonaktifkan enzim penyebab pencoklatan yaitu enzim polifenolase. Enzim polifenolase ini merupakan suatu protein sehingga ketika diblansir akan mengalami denaturasi dan aktifitasnya sebagai enzim sudah tidak berfungsi lagi. Pisang yang telah cukup mendapat pemanasan, kulitnya menjadi kusam dan layu, serta kulitnya tidak bergetah lagi jika dikupas. Pisang yang telah dingin dikupas dengan pisau. Proses selanjutnya adalah pisang yang sudah dikupas diparut menjadi bentuk yang lebih kecil untuk memudahkan pengeringan. Pengeringan dilakukan secara mekanik menggunakan oven dengan suhu $60{ }^{\circ} \mathrm{C}$ selama 24 jam. Pisang yang sudah kering kemudian dihaluskan dan diayak.

\section{Hasil dan Pembahasan}

Sale Pisang. Pisang yang dikonsumsi mentah atau diolah, baik yang berwarna hijau, setengah matang, atau buah yang matang merupakan salah satu sumber kalori yang paling signifikan untuk diet manusia di seluruh dunia. Pisang merupakan sumber kalium yang paling baik. Pisang yang memiliki warna daging buah kuning dan orange kaya akan provitamin A dan karotenoid (Nelson et al., 2006). Pisang dapat dijadikan sebagai dessert, salad buah, dapat digoreng, dan dipanggang. Bunga pisang juga dapat dimakan dalam kari, direbus, atau disop (Lim, 2012).

Pisang juga dapat diolah menjadi tepung. Hal ini dikarenakan pisang memiliki kandungan karbohidrat yang tinggi dan disimpan dalam bentuk pati. Menurut ED-informatics (2006) pisang mengandung $74 \%$ air, $23 \%$ karbohidrat, $1 \%$ protein, $0,5 \%$ lemak, dan $2,6 \%$ serat yang masing-masing nilai bervariasi tergantung pada kultivar, tingkat kematangan dan kondisi pertumbuhan. 
Buah pisang yang belum matang karbohidrat tersimpan dalam bentuk pati dan pada saat proses pematangan pati berubah menjadi gula; pisang yang sangat matang hanya memiliki $1-2 \%$ pati. Pisang dapat diolah menjadi tepung karena mengandung karbohidrat lebih dari 70 \% (Murtiningsih dan Iman Muhajir,1988 dalam Rahardi 2004), selain itu pisang dapat diolah menjadi sale.

Sale pisang (di Eropa disebut "fig") merupakan produk pisang olahan yang dibuat dengan proses pengeringan dan atau pengasapan (Prabawati dkk., 2008). Menurut Sale memiliki rasa dan aroma yang khas. Warna, rasa, bau, kekenyalan, dan ketahanan simpan merupakan sifat penting yang menentukan mutu sale. Prabawati dkk., (2008) menyatakan bahwa tingkat ketuaan buah, jenis dan mutu pisang segar yang diolah juga menentukan mutu sale.

Kriteria sale yang disukai konsumen (IPB, 1982) adalah pisang yang memiliki warna kuning kecoklatan, mengkilap, memiliki rasa manis, tidak berbau aneh, dan tidak berjamur. Warna sale yang baik adalah cokelat kekuningan atau cokelat, utuh, dan baunya normal. Badan Standarisasi Nasional menyatakan bahwa syarat mutu pisang sale kadar air maksimum $40 \%$, rasanya khas, baunya normal, tidak ada cemaran logam dan mikroba. Menurut Dupaigne (1967) berat sale adalah $19 \%$ dari berat tandan dan dikeringkan hingga kadar airnya mencapai 33 \%. Kadar air 36-38 \% merupakan kadar air maksimum yang masih ditoleransi.

Semua jenis pisang pada dasarnya dapat dijadikan sale namun hanya jenis tertentu saja yang menghasilkan rasa yang enak. Sale yang enak merupakan sale yang terbuat dari ambon, kepok, siem, raja bulu, dan emas (Prabawati dkk., 2008). Pisang emas dan Pisang Raja biasa diolah menjadi sale karena memiliki daya simpan yang lama (IPB, 1982). Jenis pisang yang sering dijadikan sale menurut (Kemenristek, 2000) adalah pisang ambon. Pisang-pisang tersebut merupakan jenis pisang yang paling sering digunakan oleh home industry karena memiliki rasa yang manis.

Sale memiliki komposisi kimia yang beragam tergantung jenis pisang yang dipilih. Kandungan $100 \mathrm{~g}$ sale pisang ambon terdapat kandungan kadar air 20,30 \%, karbohidrat 68,80 $\%$, lemak 0,80\%, protein 5,20 \%, kalsium $42 \mathrm{mg}$, fosfor $104 \mathrm{mg}$, besi 2,4 mg, vit. A 156 SI, vit B $0,32 \mathrm{mg}$, dan vit. C 13,10 mg. Sale pisang raja memiliki kandungan kadar air 17,5 \%, karbohidrat 70,20 \%, lemak 1,20\%, protein 4,30 $\%$, kalsium $39 \mathrm{mg}$, fosfor 9,6 mg, besi 1,6 mg, vit. A 160 SI, vit B 0,21 mg, dan vit. C 16,10 mg; komposisi kimia sale pisang yaitu kadar air $19,10 \%$, karbohidrat 65,90 \%, lemak 1,30\%, protein 3,80\%, kalsium $61 \mathrm{mg}$, fosfor $81 \mathrm{mg}$, besi 2,2 mg, vit.A 143SI, vit B $0,28 \mathrm{mg}$, dan vit. C 25,20 mg (Munadjim, 1983).

Penelitian yang dilakukan terhadap 6 kelompok pisang yang mengandung jumlah karbohidrat yang sama $(46.1 \pm 1.5 \mathrm{~g} / 200 \mathrm{~g}$ berat segar) tetapi komposisi berbeda tergantung tingkat kematangannya. Free sugar merupakan fraksi karbohidrat utama, meningkat sejalan dengan kematangan dari $56 \%$ hingga $75 \%$ berat kering. Sukrosa merupakan gula utama. Seiring peningkatan kematangan, jumlah pati atau tepung menurun (Englyst dan Cummings, 1986). Jenis pisang yang berbeda memiliki keunggulan masing-masing untuk pengolahan. Pisang yang paling baik dijadikan tepung pisang adalah pisang kepok karena tepung pisang yang dihasilkannya berwarna lebih putih dibanding jenis pisang yang lain (Rahardi, 2004), sedangkan pisang ambon, pisang emas, dan pisang raja merupakan jenis yang baik untuk dijadikan sale karena memiliki warna kuning kecoklatan setelah dijemur dan rasanya manis (IPB, 1982).

Buah pisang memiliki komponen hasil dan karakter buah yang berbeda dari segi warna rasa dan aroma. Tabel 1 menunjukkan tipe, warna daging buah, rasa, dan aroma beberapa jenis pisang. Pisang raja bulu, mas, ambon lumut, dan ambon putih merupakan jenis pisang yang memiliki aroma kuat dan rasa manis. Sale yang dibuat memiliki rasa yang manis perlu diperhatikan tingkat kematangan buahnya. Buah dengan tingkat kematangan yang kurang akan menghasilkan warna sale putih (Prabawati dkk., 2008). Pisang yang matang penuh dan dipotong kemudian dikeringkan secepatnya warnanya akan kuning kecoklatan, tetapi bila belum matang warnanya lebih putih dan jika terlalu matang dan tidak dikeringkan cepat warnanya menjadi lebih gelap (Wright, 1923).

Uji kadar gula beberapa jenis pisang menunjukkan bahwa pisang kapas merupakan jenis pisang yang memiliki persentasi karbohidrat tertinggi $(29,74 \%)$ yang berarti memiliki rasa yang sangat manis (Tabel 2). Selanjutnya pisang yang memiliki kadar karbohidrat tertinggi setelah pisang kapas berturut-turut adalah pisang raja $(28,95 \%)$, pisang tanduk $(27,94 \%)$, pisang lempeneng $(25,68 \%)$, pisang emas $(24,38 \%)$, 
pisang Raja Siem (23,66 \%), dan pisang ambon lumut (22,05 \%). Menurut Australia (1969) tingkat kematangan buah pisang terdapat delapan tingkatan. Semakin matang pisang warnanya akan semakin kekuningan. Pisang yang berwarna hijau memiliki kadar pati yang tinggi dengan kadar karbohidrat yang rendah. Semakin matang pisang pisang maka akan semakin baik untuk dijadikan sale karena rasanya semakin manis. Rismunandar (1989) menyatakan bahwa untuk membuat sale pilihlah pisang dengan tingkat kematangan 7-8, sebaliknya untuk membuat tepung pisang pilihlah buah dengan tingkat kematangan 1. Tabel 3 menunjukkan kadar gula dan zat tepung pisang ambon pada beberapa tingkatan masaknya buah. Semakin masak buah, kadar gula yang dimiliki akan semakin meningkat.

Berdasarkan hasil wawancara dengan pemilik home industry sale di Ciamis jenis pisang lain yang biasa digunakan untuk sale adalah pisang Siem. Menurut Prabawati dkk., (2008) pisang ambon dan pisang siem banyak digunakan karena sama-sama memiliki rasa yang sangat manis dan aroma yang kuat pada tingkat kematangan penuh.

Berdasarkan pengolahan dan bentuknya, sale terbagi ke dalam beberapa jenis yaitu sale lidah, sale, oval, sale gulung, sale jari, dan sale asap. Sale lidah, sale oval, dan sale gulung terbuat dari bahan yang sama yaitu babangi (Gambar 1). Babangi merupakan pisang yang diiris tipis-tipis dan digabungkan satu sama lain sehingga bentuknya menyerupai lembaran berukuran kira-kira $4 \mathrm{~m}^{2}$ kemudian dikeringkan. Sale yang terbuat dari babangi dikenal dengan nama sale Jawa. Umumnya babangi terbuat dari pisang siem karena jenis pisang ini bersifat mudah mengerut, saat digoreng bentuknya tetap utuh, dan mudah/banyak ditemukan di Jawa.

Sale lidah memiliki bentuk persegi $(15 \mathrm{~cm} x$ $3,5 \mathrm{~cm}$ ). Sale oval dibuat dengan cara menum-puk potongan kecil babangi sehingga berbentuk oval. Sale gulung terbuat dari babangi berukuran persegi kemudian digulung. Babangi yang telah dibentuk kemudian dimasukkan ke dalam adonan (aci dan tepung beras $6: 2$ ) lalu digoreng.

Sale jari dan sale asap terbuat dari pisang ambon karena pisang ini merupakan jenis yang baik untuk dijadikan sale jari dan sale asap. Kedua jenis sale ini umumnya diproses tanpa menggunakan gula tambahan sehingga memiliki rasa asli.Warna kedua sale ini adalah coklat tua. Peran pisang ambon sebagai bahan baku sale jari dan sale asap tidak bisa digantikan dengan jenis pisang lain karena sifat pisang ambon yang khas (rasa sangat manis dan berwarna hitam setelah dilakukan pengeringan).

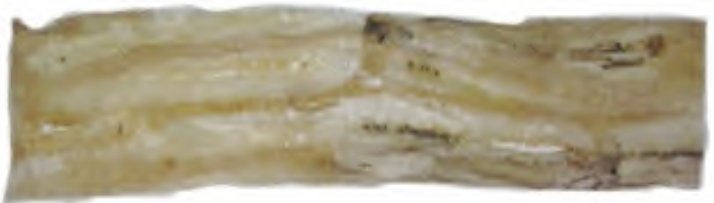

Gambar 1. Babangi sebagai bahan baku sale pisang pada home industri di Desa Cibatu Kec. Cisaat Kab. Sukabumi

Pisang-pisang yang dijadikan bahan baku sale lebih banyak didapatkan dari petani lokal/ daerah setempat karena harganya lebih terjangkau dan pisang lokal memiliki rasa yang lebih enak kecuali bahan baku sale Jawa diperoleh langsung dari Jawa dalam bentuk jadi (babangi). Pisang yang akan dibuat sale dipanen pada kondisi yang tidak terlalu matang. Pisang kemudian dikupas kemudian dijemur hingga berwarna kecoklatan. Proses pengurangan kadar air pada sale dilakukan tanpa menggunakan oven karena dapat mengurangi cita rasa sale sehingga dilakukan penjemuran. Lama penjemuran tergantung pada intensitas cahaya matahari (3-7 hari). Setelah itu pisang dipipihkan dan digoreng.

Produksi sale yang bergantung pada cahaya matahari menyebabkan produksi sale tertinggi pada musim kemarau. Pada masa musim penghujan home industry tidak banyak memproduksi sale karena sifat sale yang harus segera dijemur. Alternatif lain pembuatan sale di musim penghujan adalah dengan menggunakan pengawet (natrium bisulfat) namun hal ini tidak dilakukan oleh pemilik home industry. Sale yang telah siap kemudian dikemas untuk dipasarkan.

Uji deskripsi yang dilakukan tehadap sembilan sampel sale pisang yang dijual di Kabupaten Tasikmalaya bertujuan untuk mengidentifikasi karakteristik sensori produk (sale) dan memberikan informasi mengenai derajat atau intensitas karakteristik tersebut (Anonim, 2006). Karakter yang diuji pada sale adalah rasa manis, rasa asam, tengik, pahit, dan aroma tengik.

Proses pembuatan sale meliputi tahap pengeringan sehingga dihasilkan warna yang coklat. Beberapa sampel sale yang diuji memiliki warna yang beragam (Gambar 2).Beberapa faktor yang dapat mempengaruhi warna sale adalah jenis pisang, tingkat ketuaan pisang, dan teknik pengolahannya. Sampel-sampel yang diuji berasal dari home industry yang berbeda hal ini memungkinkan 
adanya perbedaan jenis pisang yang digunakan serta teknik pengolahan pascapanen pisang hingga pengolahan menjadi sale.

Jenis pisang yang berbeda akan menghasilkan warna yang berbeda. Menurut Munadjim (1983) pisang ambon, pisang emas, dan pisang lilin memiliki warna coklat tua setelah dijemur, sedangkan pisang raja dan pisang susu memiliki warna coklat muda. Berdasarkan hasil pengamatan sampel sale yang diperoleh, sale dari pisang ambon memiliki warna yang sangat hitam dibandingkan dengan jenis pisang lainnya. Sampel 1, 2, 3, 5, 6, 7 memiliki warna yang beragam meskipun berasal dari jenis yang sama. Hal yang dapat mempengaruhi perbedaan warna ini diantaranya adalah tingkat ketuaan buah dan lama pengeringan.

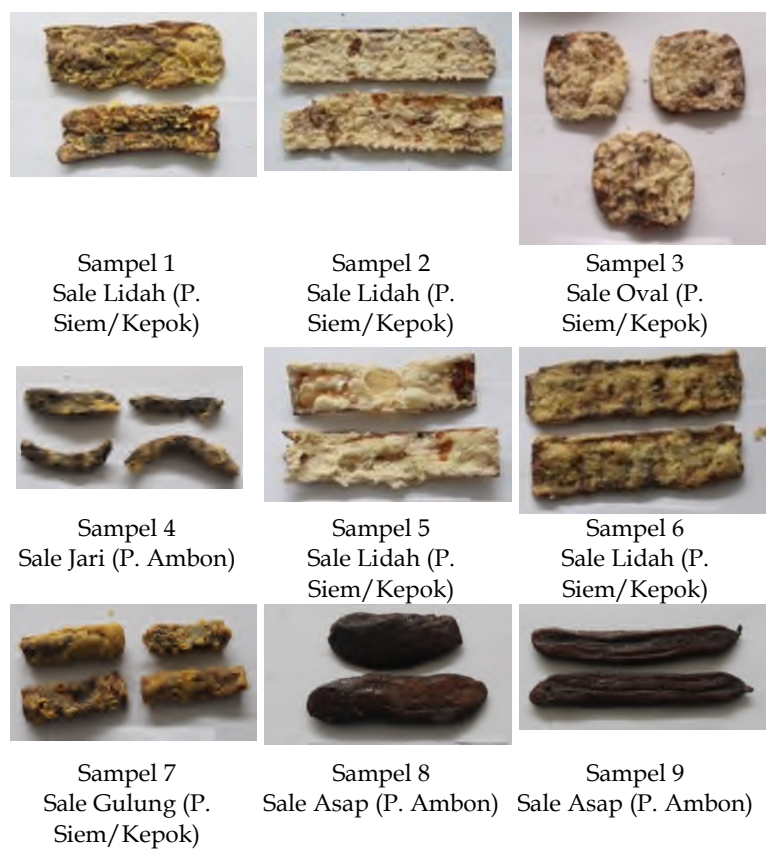

Gambar 2. Macam-macam Sale.

Keterangan : Sampel 1, 2, 5, dan 6 adalah sale lidah; sampel 3 adalah sale oval; sampel 4 adalah sale jari; sampel 7 adalah sale gulung; dan sampel 8 dan 9 adalah sale asap.

Hasil uji deskripsi (Tabel 1) menunjukkan bahwa masing-masing jenis sale memiliki sifat yang berbeda meskipun terbuat dari jenis pisang yang sama. Sampel 2 merupakan jenis sale yang memiliki tingkat kemanisan tinggi. Menurut pemilik industri sale, rasa manis pada sale dapat juga dipengaruhi oleh adonan sehingga tingkat kemanisan masing-masing sale berbeda. Rasa asam yang tinggi dimiliki oleh sampel 2 . Umumnya masing-masing sampel memiliki karakter aroma tengik yang sangat lemah. Sifat tengik yang lebih tinggi diperoleh dari cara pengolahan dan pengemasan yang tidak baik.
Tabel 1. Hasil Uji Deskripsi 9 Sampel Sale Pisang.

\begin{tabular}{lccccc}
\hline \hline \multicolumn{1}{c}{ Sampel } & $\begin{array}{c}\text { Rasa } \\
\text { Manis }\end{array}$ & $\begin{array}{c}\text { Rasa } \\
\text { Asam }\end{array}$ & Tengik & Pahit & $\begin{array}{c}\text { Aroma } \\
\text { Tengik }\end{array}$ \\
\hline 1. Sale lidah & 1,4 & 4,2 & 2,4 & 1,2 & 1,6 \\
2. Sale lidah & 3,2 & 1,8 & 1 & 1 & 1 \\
3. Sale oval & 2,6 & 1,4 & 1 & 1,8 & 1,4 \\
4. Sale jari & 4 & 1,6 & 1,2 & 1,8 & 1,2 \\
5. Sale lidah & 2,4 & 1 & 1,4 & 1,4 & 1,2 \\
6. Sale gulung & 3 & 2,4 & 1,4 & 1,4 & 1 \\
7. Sale gulung & 2,4 & 1,8 & 2 & 1 & 2,2 \\
8. Sale asap & 2,4 & 3,2 & 1 & 2,2 & 2,6 \\
9. Sale asap & 3 & 1,6 & 1 & 1,4 & 1 \\
\hline \hline
\end{tabular}

Keterangan : rentang 1-6 mengindikasikan sifat sangat lemah hingga sangat kuat

Uji hedonik dilakukan untuk mengetahui tingkat kesukaan panelis terhadap sampel yang diuji. Tingkat kesukaan ini disebut skala hedonik, misalnya sangat suka, suka, agak suka, agak tidak suka, tidak suka, sangat tidak suka dan lain-lain (Anonim, 2006).Tingkat kesukaan yang diuji meliputi rasa, aroma, dan tekstur (Tabel 2). Sampel pisang yang paling disukai dari segi rasa adalah sampel 2, sampel 9, sampel 3, dan sampel 5. Keempat sampel disukai karena dari segi rasa memiliki proporsi manis yang lebih besar dengan rasa asam dan tengik yang lemah.

Tabel 2. Uji Hedonik Rasa, Aroma, dan Tekstur 9 Sampel Sale Pisang.

\begin{tabular}{lccccccccc}
\hline \multirow{2}{*}{ Karakter Sampel } \\
\cline { 2 - 9 } & 1 & 2 & 3 & 4 & 5 & 6 & 7 & 8 & 9 \\
\hline Rasa & 2,4 & 5,8 & 3,8 & 3,6 & 3,8 & 2,6 & 4 & 2,6 & 4,4 \\
\hline Aroma & 3,6 & 4,8 & 4,4 & 4,2 & 4 & 3,8 & 3,6 & 2,6 & 4,4 \\
\hline Tekstur & 3,6 & 5,4 & 4,2 & 3,4 & 2,8 & 2,2 & 3,6 & 2,8 & 4,4 \\
\hline \hline Keterangan: 1 = sangat tidak suka; 2 = tidak suka; 3= \\
agak tidak suka; 4 = agak suka; 5 = suka; \\
6 = sangat suka; 7 = sangat suka sekali
\end{tabular}

Aroma pisang yang disukai berturut-turut adalah sampel 2, sampel 3, sampel 4, sampel 5, dan sampel 6. Sampel-sampel tersebut memiliki aroma sale yang khas. Jika dibandingkan dengan hasil pada uji deskripsi sebelumnya sampel tersebut memiliki penilaian aroma tengik yang lemah sehingga aroma khas pisang dapat tercium. Uji deskripsi terhadap tekstur menunjukkan bahwa penguji lebih menyukai sampel 2 dibanding sampel yang lainnya dengan nilai 5,2. Sampel yang agak disukai dari segi tekstur adalah sampel 3 dan 9, sedangkan sampel yang tidak disukai dari segi tekstur adalah sampel 6. Alasan panelis menyukai sampel tersebut karena tekstur yang tidak liat atau mudah digigit. 
Tepung Pisang. Menurut Palupi (2012), jenis pisang memberikan pengaruh nyata pada kadar air, protein, lemak, abu, serat kasar, pati, rendemen, warna, serta organoleptik (warna, tekstur dan aroma). Tepung pisang yang terbuat dari pisang kepok sangat baik hasilnya karena warna tepungnya putih dan menarik. Menurut Gardjito dalam Republika (2006) pisang yang paling baik untuk diolah menjadi tepung adalah pisang tanduk (Musa paradisiacal fa Corniculata). Kedua jenis pisang tersebut termasuk kedalam jenis pisang plantain. Histifarina, dkk (2012) melaporkan bahwa Jenis pisang nangka menghasilkan tepung pisang dengan nilai rendemen terbaik dan jenis pisang siam dari segi penilaian kesukaan terhadap warna.

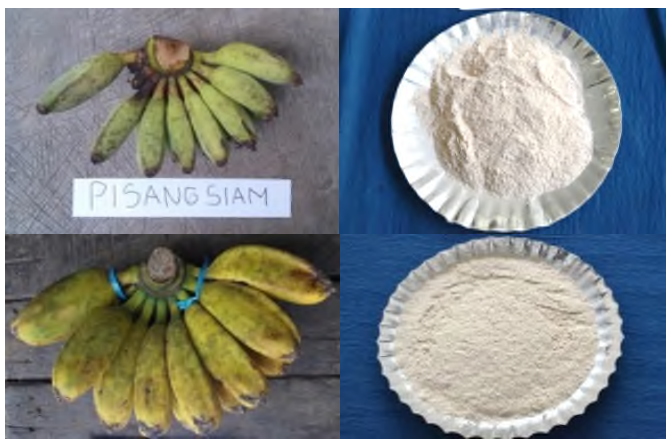

Gambar 3. Hasil Tepung dari Pisang Kepok dan Pisang Siam.

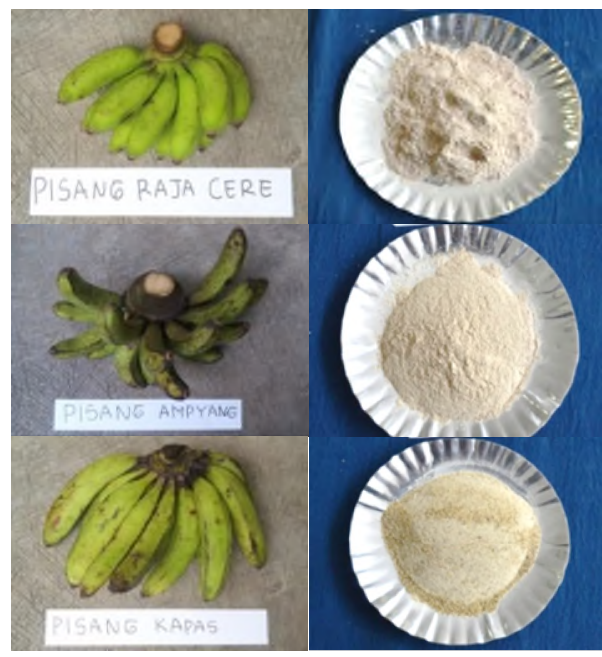

Gambar 4. Tepung yang dihasilkan dari Pisang Raja Sere, Pisang Ampyang, dan Pisang Kapas.

Semua jenis pisang dapat dijadikan tepung dari jenis banana dan plantain namun jenis pisang yang lebih baik dijadikan tepung adalah dari jenis plantain. Menurut Palupi (2012) pisang jenis plantain memiliki kadar pati yang lebih tinggi dan kadar gula yang lebih rendah dibandingkan jenis banana. Menurut penelitian Histifarina dkk., (2012) dan Palupi (2012) melaporkan bahwa walaupun jenis bahan rendaman dan tipe pengeringan memberikan pengaruh terhadap kualitas tepung yang dihasilkan namun pengaruh jenis pisang yang digunakan memberikan pengaruh yang lebih besar dalam kualitas tepung.

Percobaan pembuatan tepung dilakukan pada sepuluh jenis pisang yang mendominasi di Jawa Barat yaitu pisang ambon kuning, nangka, siem/apu/jimluk muli/lampung, raja sere, kapas, raja bulu, tanduk, siripit, dan ambon lumut. Pisang siripit tidak diolah menjadi tepung karena tidak ditemukannya pisang tersebut di pasar. Selain pisang-pisang tersebut pisang kepok, pisang ampyang dan pisang susu juga dicoba diolah menjadi tepung karena pisang kepok adalah jenis pisang yang sering digunakan sebagai bahan baku tepung sedangkan pisang ampyang dan pisang susu adalah jenis pisang yang cukup banyak ditemukan dipasar.

Analisis yang dilakukan pada tepung yang dihasilkan adalah dari warna tepung yang dihasilkan oleh masing-masing pisang tersebut. Analisis warna atau tingkat keputihan dari tepung yang dihasilkan erat kaitanya dengan mutu penerimaan konsumen karena umumnya konsumen lebih menyukai bahan pangan yang berwarna putih bersih terutama bahan pangan yang berupa tepung (Histifarina, 2012). Pengukuran derajat putih dilakukan dengan membandingkan warna tepung yang satu dengan yang lainnya.

Tepung yang dihasilkan oleh pisang-pisang tersebut menunjukan bahwa Pisang Kepok memiliki warna tepung paling cerah, warna tepung yang dihasilkan hampir sama dengan yang dihasilkan oleh Pisang Siem. Warna tepung yang dihasilkan oleh kedua pisang tersebut lebih cerah dibandingkan dengan pisang jenis lainnya. Histifarina (2012) menyebutkan hal yang sama bahwa pisang siem dan pisang kepok memiliki warna yang lebih putih. Pisang Raja Sere menunjukan warna kecerahan yang hampir sama dengan pisang siem. Selanjutnya urutan pisang yang memiliki warna putih lebih baik adalah pisang ampyang kemudian pisang kapas.

Tepung yang dihasilkan dari pisang nangka dan pisang tanduk berwarna kekuningan. Warna tepung yang dihasilkan sangat dipengaruhi oleh warna dari daging buah 
pisang (Histifarina, 2012). Daging buah kedua pisang tersebut saat setelah dikukus (blansir) menunjukan warna kekuningan. Blansir juga dapat menimbulkan efek cerah dan memunculkan warna kuning dari $\beta$-karoten

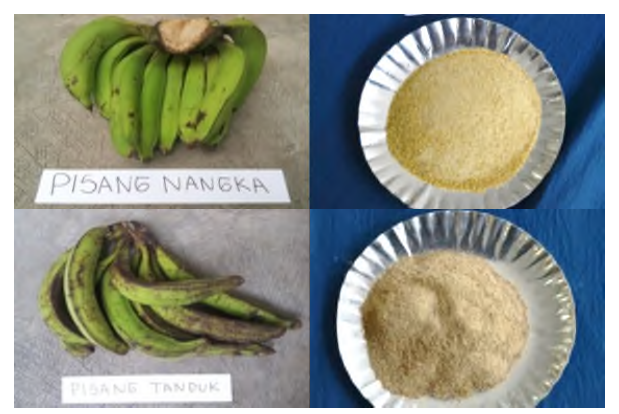

Gambar 5. Hasil Tepung dari Pisang Nangka dan Pisang Tanduk.

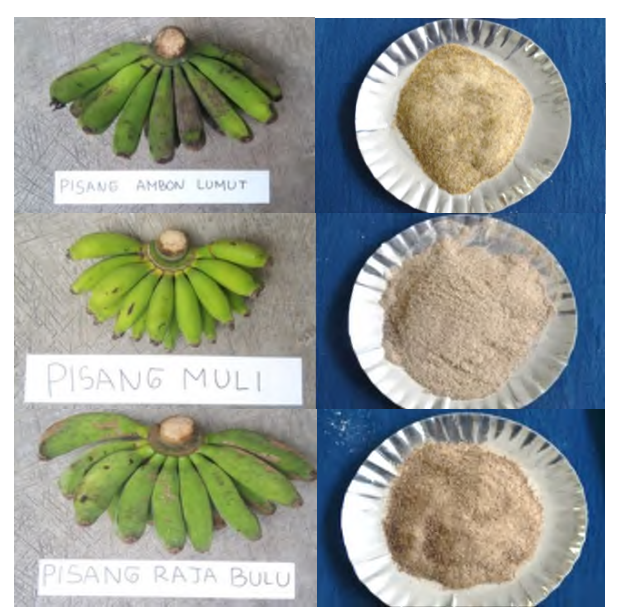

Gambar 6. Tepung Pisang yang Dihasilkan dari Hasil Pisang Ambon Lumut, Pisang Muli, dan Pisang Raja Bulu.

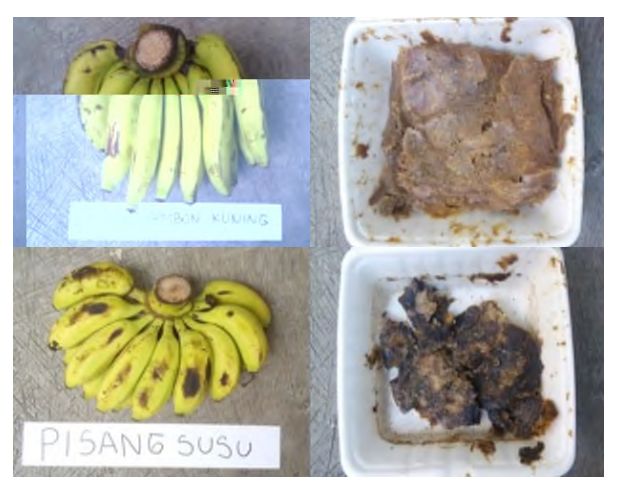

Gambar 7. Hasil Pisang Ambon Kuning dan Pisang Susu setelah Pengeringan.
Pisang ambon lumut dan pisang muli menghasilkan warna tepung yang kecoklatan. Kedua pisang tersebut cepat berubah kecoklatan (browning), hal tersebut terlihat karena saat sebelum dikeringkan warna kedua daging buah tersebut berwarna kekuningan. Tepung yang dihasilkan dari pisang raja bulu memiliki warna coklat kemerahan, warna tersebut dari warna biji pisang raja bulu. Pisang raja bulu memiliki biji yang cukup banyak dibandingkan jenis pisang lainnya dengan jumlah daging buah yang sedikit.

Pisang ambon kuning dan pisang susu yang diolah menjadi tepung tidak berhasil. Terjadinya hal tersebut dikarenakan pisang yang digunakan sudah cukup matang. Tekstur kedua pisang tersebut setelah dikukus berubah menjadi lunak hal tersebutlah yang menandakan pisang sudah terlalu matang untuk dijadikan tepung. Pisang yang matang tidak dapat diolah menjadi tepung karena kandungan pati dalam buah sudah berubah menjadi gula.

\section{Kesimpulan}

Masing-masing daerah di Jawa Barat memiliki potensi pengembangan produk kea rah sale yang berbeda. Pisang ambon kuning merupakan jenis pisang yang diketahui memiliki ketersediaan bahan baku yang tinggi dilihat dari indeks nilai penting di setiap dataran. Pisang siem, kapas, dan raja bulu juga merupakan jenis pisang sale yang tersebar, namun pemanfaatannya pada masingmasing dataran memiliki prioritas yang pengembangan produk yang berbeda.

\section{Ucapan Terima Kasih}

Terima kasih kami ucapkan kepada Fakultas Pertanian Universitas Padjadjaran yang telah mendanai penelitian ini melalui Skema Hiibah Kompetitif Fakultas Tahun 2015.

\section{Daftar Pustaka}

Anonim. 2006. Pengujian Organoleptik (Evaluasi Sensori) dalam Industri Pangan. ebookpangan.com.

Astawan, Made. 2005. Pisang buah kehidupan. Kompas, 10 Agustus 2005. 
Australia. 1969. The Mixed-ripe Problem of Bananas. Banana Research Advisory Committee: Australia.

Bappenas. 2000. Pisang (Musa spp). Editor : Kemal Prihatman. Sistim Informasi Manajemen Pembangunan.

BPS. 2015. Tabel dinamik produksi tanaman hortikultura. bps.go.id diakses 27 Mei 2015

Dupaigne, P. 1967. Le contrôle de la qualité des bananes scéhéés. Fruits, 22, 27-29.

Englyst, Hans N. dan John H Cumings, FRCP. 1986. Digestion of the carbohydrates of banana (Musa paradisiaca sapientum) in the human small intestine. The Am. J. of Clinical Nutr. 4: July 1986, p 42-50.

EDinformatics. 2006. Banana. Tersedia pada: http://www.edinformatics.com/culinarya rts/food_encyclopedia/banana.htm.

Diakses pada tanggal 21 Desember 2014.

Heyne, K. 1950. De Nuttige Planten van Indonesia. N. V. Uitgeverij W. van Hoeve, Netherlands.

Histifarina, D., Adetiya Rachman, Didit Rahadian, dan Sukmaya. 2012. Teknologi pengeolahan tepung dari berbagai jenis pisang menggunakan cara pengeringan matahari dan mesin pengering. Agrin Vol. 16, No.2, Oktober 2012 ISSN: 1410-0029

IPB. 1982. Pisang Sale: Paket Industri Pangan untuk Daerah Pedesaan. Pusat Penelitian dan Pengembangan Teknologi Pangan Institut Pertanian Bogor: Bogor.

Lim, T. K. 2012. Edible medicinal and non medicinal plants: Fruits Volume 3,.

Munadjim. 1983. Teknologi Pengolahan Pisang. PT. Gramedia: Jakarta.

Nelson, Scot C., Randy C. Ploetz, dan Angela Kay Kepler. 2006. Species Profiles for Pacific Island Agroforestry: Musa Species (Banana and Plantain). Permanent Agriculture Resources: USA.

Prabawati, S., Suyanti, dan Dondy A. Setyabudi. 2008. Teknologi Pascapanen dan Teknik Pengolahan Buah Pisang. Badan Penelitian dan Pengembangan Pertanian.

Palupi, Hapsari Titi. 2012. Pengaruh jenis pisang dan bahan perendam terhadap karakteristik tepung pisang (Musa spp). Jurnal Teknologi Pangan Vol. 4 No. 1.

Rahardi, A. 2004. Teknologi Pangan dan Agroindustri Vol. I Nomor 8, IPB Press, Bogor.

Republika. 2006. Pisang, si kaya gizi dan khasiat. Republikaonline

Rismunandar. 1989. Bertanam Pisang. Sinar Baru, Bandung.

Satuhu, Suyanti dan Ahmad Supryadi. 1992. Pisang: Budi Daya, Pengolahan, dan Prospek Pasar. Penebar Swadaya: Depok.

Wright, C. Harold. 1923. Dried bananas. Tropical Agriculturist Vol-LX, Jan-June 1923. 